\title{
EIF2B4 Gene
}

National Cancer Institute

\section{Source}

National Cancer Institute. EIF2B4 Gene. NCI Thesaurus. Code C38548.

This gene is involved in both the initiation and regulation of protein synthesis. 